\title{
Understanding the Work Values of Chinese Employees
}

\author{
Xiaochuan Jiang ${ }^{1,2}$, Jianfeng Yang ${ }^{3}$ \\ ${ }^{1}$ Institute of Industrial Economics, Jiangxi University of Finance and Economics, Jiangxi, China; \\ ${ }^{2}$ School of Politics and Law, Jiangxi Normal University, Jiangxi, China; \\ ${ }^{3}$ Research Center of Cluster and Enterprise Development, Jiangxi University of Finance and Economics, \\ Jiangxi, China. \\ Email: nanch37@yahoo.com.cn \\ Received June $2^{\text {nd }}, 2011$; revised July 9 $9^{\text {th }}, 2011$; accepted August $12^{\text {th }}, 2011$.
}

\begin{abstract}
This study aimed to explore work values in Mainland China. A total of 1,155 Chinese employees participated in this study by filling out questionnaires. Data was analysed using factor analysis, analysis of variance, and regression. Results showed that Chinese employee emphasized social harmony and self-realization the most, followed by prosperous development and material conditions. There were substantial relationships between work values and gender, age, hierarchical levels, and organizational performance. However, tenure and organizational size had no significant effect on work values.
\end{abstract}

Keywords: Work Values, Chinese, Employee, Collectivism, Social Harmony

Although traditional Chinese culture has influenced Chinese people over thousands of years, strong winds of change have been blowing across China during the last thirty years (Lan et al., 2009). Work values of Chinese employees have evolved gradually, so research on today's Chinese work values can provide international human resource managers with valuable information, helping them employ, predict, and manage employees' behavior. The current study aimed to investigate work values of Chinese employees and to determine the effects of individual characteristics and institutional characteristics on their work values.

Values are transituational goals that work as major principles of an individual or an organization (Schwartz \& Rubel, 2005). Work values are an important subset of values (Posner et al., 1987). They are norms that employees use to judge and to choose among alternative modes of behavior (Becker and McClintock, 1967).Therefore, understanding employees' work values has great influence on the effectiveness, efficiency, and morale of organizations (Viola, 1977).

\section{Research on Work Values in China}

Chinese researchers have used Western questionnaires to investigate Chinese employees' work values in the last decade and have gotten some valuable information about Chinese employees' work values (e.g., Weiwei, 1999; Hua \& Xiting, 2000). However, there may be two issues needed to be noticed.

First, work values are results of the interactive effect between personality and environment (Holland, 1985). In the last half century, Chinese social environment have been transformed substantially. Those changes must influence Chinese employees' work values (Whitcomb et al., 1998). Since 1978, China has been changing from a centrally planned economy to a market economy with Chinese characteristics gradually. This transformation make Chinese people more open to the world. Furthermore, in the past several years, there are many natural disasters, including earthquakes (e.g., Wenchuan), epidemics (e.g., SARS), and flooding (e.g., Jiangxi). On one hand, those disasters caused the Chinese to suffer greatly. On the other hand,

*This research was supported by grants from the Chinese National Scientific Foundation (71002112). they encouraged Chinese people to embrace certain values, such as solidarity, patriotism, health, and security (Yan et al., 2008). Finally, the 2008 Beijing Olympics and the 2010 Shanghai World Exposition further enhanced the values of solidarity and patriotism in China.

Second, as suggested by Huang (1995) and Neitai (2010) that the influence of social environment on work values is so strong that there may be substantial differences between dimensions of Western work values and those of Chinese work values, researchers should come up with specific dimensions of Chinese work values. Recently, basing on the research of Huang (1995) and Elizur et al., (1991), Neitai (2010) came up with a fourdimensions model of Chinese work values: 1) material conditions, stresses the self-material repayment of work, such as payment, welfare, and working hours; 2) self-realization, stresses the inner experience gained from work, such as interest, accomplishment, skill diversity, independence, and creativity; 3) social harmony, emphasizes to harmonize the relationships between people and between organizations, such as family concord and getting along well with leaders; 4) prosperous development, accents material contribution to society, including helping colleagues resolve difficulties, boosting company performance, advancing country competition, and serving people.

\section{The Impact of Individual Characteristics}

Age. As China establishes its market economy, social competition has become increasingly intense. There is great pressure on young people, many of whom are a family's only child, to succeed so that their families can survive (Lan et al., 2009). Consequently, younger people might stress values of achievement more than elder people.

Younger people experience the influence of Western values more than older people. They learn English as a second language; Western traditions, customs, and holidays, such as Valentine's Day and Christmas, are increasingly popular among Chinese young adults (Lan et al., 2009). There is more freedom to express their own opinions, and the Internet makes the world more accessible to them. Younger people experience the dimension of self-realization more than elder people. Therefore, elder people tend to be more collectivistic and less individualis- 
tic, more conservative and less open to change, and more selftranscendent and less self-enhancing (Erikson, 1997).

Gender. Traditional Chinese culture emphasized the different roles played by males and females in society (Lan et al., 2009). For thousands of years, Chinese males controlled the world, and females were simply auxiliaries to males. There was an old belief that "ignorance is a woman's virtue". Women's success relied on the harmony of the family, the happiness of husbands, and the education of children.

After 1949, the Chinese government to a great extent have acknowledged the worth of women. Now, women need not adopt their husband's family name after they marry. After graduating from schools, many women are employed as marketers, ad-agents, and managers, so they can contribute to the economic base of their family. Furthermore, because of the one-child policy, many parents provide more opportunities for their daughters to receive a good education and to find a successful career (Lan et al., 2009). Thus, in China, women enjoy near social equality as an important part of the workforce.

\section{The Impact of Organizational Characteristics}

People who always work together tend to develop shared values, which may differ from the shared values of people in other areas with whom there is less frequent contact (Enz, 1985). Organizational characteristics, such as organizational performance and organizational size, can influence managers' values (Posner et al., 1985, Posner et al., 1987). For example, Manufacturing, compared to other functions in business organizations, is more tied to routine and technological demands. Therefore, manufacturing managers rate the areas of flexibility, competitiveness, and creativity less important than other managers do (Posner et al., 1987).

\section{The Aims of This Study}

Although work values have been frequently researched, there is still a considerable gap regarding the data from today's Chinese mainland. This study aimed to contribute to Chinese work values research by exploring its descriptive nature. Furthermore, we had two research questions to be put forward:

1) Among today's Chinese employee, are there certain individual characteristics such as age and gender that are influential over holding certain work values?

2) Among today's Chinese employee, are there certain organizational characteristics such as size and performance that are influential over holding certain work values?

\section{Methods}

\section{Samples}

A self-report questionnaire was distributed to each of 1,302 employees in 25 companies of 5 sectors: food, textiles, chemi$\mathrm{cal}$, architecture, and real estate. Completed questionnaires were collected though trained research assistants at the companies over one week. The demographics of the 1,155 participants ( $89 \%$ of our sample) who completed the entire questionnaire and provided demographic information are outlined in Table 1.

\section{Measures}

The 18-item Chinese Work Values Questionnaire (Neitai, 2010) was used. The questionnaire measured four dimensions of Chinese work values: social harmony, self-realization, material conditions, and prosperous development. The participants
Table 1.

Demographics of the participants.

\begin{tabular}{|c|c|c|}
\hline Tenure & & \\
\hline Mean & SD & Range \\
\hline 7.9 & 8.4 & $1-42$ \\
\hline \multicolumn{3}{|l|}{ Age } \\
\hline Mean & SD & Range \\
\hline 33.8 & 9.0 & $18-67$ \\
\hline \multicolumn{3}{|l|}{ Age range frequency } \\
\hline & $n$ & $\%$ \\
\hline $0-20$ & 10 & $0.9 \%$ \\
\hline $20-30$ & 529 & $45.8 \%$ \\
\hline $31-40$ & 361 & $31.3 \%$ \\
\hline $41-50$ & 192 & $16.6 \%$ \\
\hline $51-60$ & 59 & $5.1 \%$ \\
\hline$>60$ & 4 & $0.3 \%$ \\
\hline \multicolumn{3}{|l|}{ Gender } \\
\hline & $n$ & $\%$ \\
\hline Male & 690 & $59.7 \%$ \\
\hline Female & 465 & $40.3 \%$ \\
\hline \multicolumn{3}{|l|}{ Hierarchical level } \\
\hline & $n$ & $\%$ \\
\hline General Staff & 606 & $52.5 \%$ \\
\hline Monitor & 260 & $22.5 \%$ \\
\hline Middle manager & 228 & $19.7 \%$ \\
\hline Top manager & 61 & $5.3 \%$ \\
\hline
\end{tabular}

rated the importance for each item using a 6-point Likert scale $(1=$ very unimportant and $6=$ very important $)$. We constructed a score for each dimension of work values for each participant as the mean of their corresponding items.

We measured organizational size based on the number of employees ( 1 = less than 50 employees, 2 = 50 to 100 employees, 3 = 100 to 500 employees, 4 = 500 to 1000 employees, 5 = 1000 to 1500 employees, 6 = more than 1500 employees) and measured organizational performance based on organizational annual revenues $(1=$ less than 5 million $R M B, 2=5$ million to 300 million $R M B, 3=$ more than 300 million $R M B)$. The demographic characteristics were measured in the following way: Respondents were asked to indicate their sex $(1=$ female, 2 = male $)$, hierarchical level $(1=$ general staff, 2 = monitor, 3 = middle manager, 4 = top manager).

\section{Results and Discussion}

Using AMOS 5.0 to perform a confirmatory factor analysis, we found that the 4-dimension model was acceptable: RMSEA $=0.070(95 \% \mathrm{CI}[0.066-0.074]), \mathrm{CFI}=0.93, \mathrm{NFI}=0.92, \mathrm{RFI}$ 
$=0.90$, IFI $=0.91$. Cronbach's alphas for all 4 dimensions were bigger than 0.72 . Therefore, the Chinese values questionnaire is acceptable.

From Table 2, Chinese employees valued social harmony and self-realization the most, followed by prosperous development and material conditions $(F=180.23, d f=3, p<.001)$. They wanted to realize social harmony in and through their work. This finding may be the outcome of a traditional Chinese belief called the "Pursuit of Harmony".
Female placed more emphasis on material conditions $(t=$ $-4.77, p<.001)$ and self-realization $(t=-3.08, p<.01)$ than did male (see Table 3 ). This result is a little inconsistent with the findings of Western studies that suggested females placed more importance on the values of universalism and benevolence and less on power than males, whereas males consistently emphasized power, stimulation, hedonism, achievement, and self-direction more than females (e.g., Lindeman \& Verkasalo, (2005) Schwartz \& Rubel, (2005)). This difference may be due

Table 2.

Factor analysis results of work values.

\begin{tabular}{|c|c|c|c|c|c|c|c|c|c|c|c|c|}
\hline & $M$ & $S D$ & $\alpha$ & 1 & 2 & 3 & 4 & 5 & 6 & 7 & 8 & 9 \\
\hline 1. Age & 33.80 & 8.95 & & - & & & & & & & & \\
\hline 3. Tenure & 7.95 & 8.45 & & .67 & .11 & - & & & & & & \\
\hline 4. Hierarchical level & 3.18 & 0.94 & & -.39 & -.14 & -.18 & - & & & & & \\
\hline 5. Organizational size & 4.01 & 1.47 & & .12 & .09 & .31 & .02 & - & & & & \\
\hline 6. Organizational performance & 2.59 & 0.53 & & .08 & .06 & .15 & -.03 & .51 & - & & & \\
\hline 7. Material conditions & $4.04^{\mathrm{c}}$ & 0.99 & .75 & -.12 & -.14 & -.03 & .22 & -.02 & -.09 & & & \\
\hline 8. Self-realization & $4.66^{\mathrm{b}}$ & 0.95 & .84 & -.12 & -.09 & -.04 & -.09 & .04 & .01 & .33 & & \\
\hline 9. Social harmony & $4.85^{\mathrm{a}}$ & 0.87 & .72 & -.07 & -.05 & -.01 & .02 & -.01 & -.03 & .35 & .52 & \\
\hline 10. Prosperous development & $4.06^{\mathrm{c}}$ & 1.28 & .94 & -.03 & -.03 & .01 & .01 & .02 & -.02 & .29 & .49 & .57 \\
\hline
\end{tabular}

Note: $n=1,155$. Correlation coefficients whose absolute values are larger than .07 are significant at .05 level. Correlation coefficients whose absolute values are larger than .09 are significant at .01 level. Parameter estimates in each column that share subscripts do not differ significantly.

Table 3.

Effects of gender, age, and hierarchical level on work values.

\begin{tabular}{|c|c|c|c|c|c|c|c|c|}
\hline & \multicolumn{2}{|c|}{ Material conditions } & \multicolumn{2}{|c|}{ Self-realization } & \multicolumn{2}{|c|}{ Social harmony } & \multicolumn{2}{|c|}{ Prosperous development } \\
\hline & $M$ & $S D$ & $M$ & $S D$ & $M$ & $S D$ & $M$ & $S D$ \\
\hline \multicolumn{9}{|l|}{ Gender } \\
\hline Male & 3.93 & 1.00 & 4.59 & 0.95 & 4.82 & 0.88 & 4.04 & 1.30 \\
\hline Female & 4.21 & 0.94 & 4.77 & 0.93 & 4.91 & 0.86 & 4.11 & 1.25 \\
\hline$t$ & $-4.77^{* * *}$ & & $-3.08^{* *}$ & & -1.59 & & -0.90 & \\
\hline \multicolumn{9}{|l|}{ Age } \\
\hline Younger people & 4.08 & 0.97 & 4.71 & 0.92 & 4.87 & 0.86 & 4.08 & 1.26 \\
\hline Older people & 3.91 & 1.04 & 4.52 & 1.03 & 4.82 & 0.91 & 4.04 & 1.37 \\
\hline$t$ & $2.36^{*}$ & & $2.60^{* *}$ & & 0.77 & & 0.33 & \\
\hline \multicolumn{9}{|l|}{ Hierarchical level } \\
\hline Staff & $4.20_{\mathrm{a}}$ & 0.96 & $4.62 \mathrm{~b}$ & 0.99 & 4.88 & 0.89 & 4.06 & 1.34 \\
\hline Monitor & $4.02_{b}$ & 0.96 & $4.63_{\mathrm{b}}$ & 0.88 & 4.88 & 0.82 & 4.13 & 1.15 \\
\hline Middle manager & $3.78_{\mathrm{b}}$ & 1.00 & $4.73_{\mathrm{b}}$ & 0.94 & 4.82 & 0.87 & 4.02 & 1.25 \\
\hline Top manager & $3.44_{\mathrm{c}}$ & 1.00 & $5.06_{\mathrm{a}}$ & 0.89 & 4.84 & 0.82 & 4.03 & 1.41 \\
\hline$F$ & $17.62^{* * *}$ & & $4.05^{* *}$ & & 0.27 & & 0.28 & \\
\hline
\end{tabular}

Note: Parameter estimates in each column that share subscripts do not differ significantly. Younger people indicate the participants are less than 30 years old. Older people indicate the participants are more than 30 years old. ${ }^{*} p<0.05,{ }^{* *} p<0.01$. 
to traditional Chinese culture that encourages male rather than female to contribute to society and country. Furthermore, Chinese female's self-awareness just began to wake up, they strive to the equity between female and male as soon as possible, so they would like to place more emphasis on the rewards of work than males do.

There was a significant negative relationship between age and material condition $(r=-0.12, p<.01)$ and self-realization $(r=-0.12, p<.01)$ (see Table 2). Furthermore, comparing younger participants (less than 30 years old) and older participant (more than 30 years old), we found that younger participants place more emphasized on material condition $(t=2.36, p$ $<.05)$ and self-realization $(t=2.60, p<.01)$ than older practitioners did (see Table 3 ). Because of different living and work experiences, younger people are more susceptible to materialism and individualism and experience more intense selfawareness than elder people. Consequently, younger people want to achieve greater material and psychological rewards form their work than elder people do. Furthermore, most of younger people are single children. They are the "little suns" of their families. Therefore, they want their work environment to be both materially and psychology fulfilling.

Hierarchical levels influenced material conditions $(F=17.62$, $p<.001)$ and self-realization $(F=4.05, p<.01)$ substantially. Ascending the hierarchical level, business practitioners place more stress on self-realization and less on material conditions. High-level employees generally have better material conditions than low-level employees. According to Maslow's hierarchy of needs theory, they are tend to value self-realization more than material conditions.

Regressing organizational performance on work values, statistically controlling the effects of gender, age, tenure, hierarchical level, and organizational size, we found that with an increase in organizational performance, employees placed less emphasis on material conditions $(B=-0.09, p<.05)$. Employees working in companies with higher organizational performance would have better working conditions and material benefits. Thus, they would express less desire for material conditions. Finally, organizational size did not impact work values substantially.

As in any empirical study, our project has limitations. First, the issue of social desirability might be a concern. As previous research, we ask participants to judge importance of every items, then participants might have thought some kinds of work values were important only because they believed these items

Table 4.

Predictors of work values.

\begin{tabular}{ccccc}
\hline & $\begin{array}{c}\text { Material } \\
\text { conditions }\end{array}$ & Self-realization & $\begin{array}{c}\text { Social } \\
\text { harmony }\end{array}$ & $\begin{array}{c}\text { Prosperous } \\
\text { development }\end{array}$ \\
\hline Age & $-0.10^{*}$ & $-0.19^{* *}$ & -0.08 & -0.04 \\
Gender & $0.10^{* *}$ & $0.11^{* *}$ & 0.05 & 0.04 \\
Tenure & 0.06 & 0.05 & 0.08 & 0.03 \\
$\begin{array}{c}\text { Hierarchical } \\
\text { level }\end{array}$ & $-0.19^{* *}$ & $0.15^{* *}$ & -0.01 & -0.01 \\
$\begin{array}{c}\text { Organizational } \\
\text { size }\end{array}$ & 0.03 & 0.06 & -0.03 & 0.05 \\
$\begin{array}{c}\text { Organizational } \\
\text { performance }\end{array}$ & $-0.09^{*}$ & 0.00 & -0.01 & -0.05 \\
\hline $\begin{array}{c}\text { Note: } \\
\text { coefficient. }\end{array}$. $0.05,{ }^{* *} p<0.01$. All the coefficients are standardized regression \\
\hline
\end{tabular}

are socially correct. Second, the sample of this study is a conventional one. However, our sample size was very large, ensuring a diverse and representative sample. In future, we should use more valid methods to measure work values and get more random samples.

\section{References}

Allport, G. W., Vernon, P. E., \& Lindzey, G. (1960). Study of values. Boston: Houghton Mifflin.

Becker, G. M., \& McClintock, G. G. (1967). Value: Behavioral decision theory. Annual Review of Psychology, 18, 239-286. doi:10.1146/annurev.ps.18.020167.001323

Berrin, E., Maria, L. K., \& Robert, C. L. (2004). Work value congruence and intrinsic career success: The compensatory roles of leadermember exchange and perceived organizational support. Personnel Psychology, 57, 305-332. doi:10.1111/j.1744-6570.2004.tb02493.x

Buchholz, R. A. (1977). The belief structure of managers relative to work concepts measured by a factor analytic model. Personnel Psychology, 30, 567-587. doi:10.1111/j.1744-6570.1977.tb02328.x

Chan, R. Y. K., Wong, Y. H., \& Leung, T. K. P. (2008). Applying ethical concepts to the study of "green" consumer behavior: An analysis of chinese consumers' intentions to bring their own shopping bags. Journal of Business Ethics, 79, 469-481. doi:10.1007/s10551-007-9410-8

Elizur, D., Borg, I., Hunt, R., \& Beck, I. M. (1991). The structure of work values: A cross cultural comparison. Journal of Organizational Behavior, 12, 21-38.doi:10.1002/job.4030120103

Enz, C. A. (1985). Power and shared values. Ann Arbor: University of Michigan Press.

Erikson, E. H. (1997). The life cycle completed. Extended Version with New Chapters on the Ninth Stage of Development by Joan M. Erikson, New York: W.W. Norton.

Feather, N. T. (1982). Expectations and actions. London: LEA.

Feather, N. T. \& Rauter, K. A. (2004). Organizational Citizenship behaviours in relation to job status, job insecurity, organizational commitment and identification, job satisfaction and work values. Journal of Occupational \& Organizational Psychology, 77, 81-94. doi: 10.1348/096317904322915928

Gay, E., Weiss, D., Hendel, D., Dawis, R., \& Lofquist, L. H. (1975) The minnesota importance questionnaire. Minneapolis: University of Minnesota.

Holland, J. L. (1973). Making vocational choices: A theory of careers. Englewood Cliffs, NJ: Prentice-Hall.

Holland, J. L. (1985). Making vocational choicess: A theory of vocational personalities and work environment. Englewood Cliffs, NJ: Prentice-Hall,

Hua, Y., \& Xiting, H. (2000). A comparision of work value of undergraduates and upcountry employees. Psychological Science, 23, 739740 .

Huang, G. G. (1995). Comparing the work values of taiwan and mainland. Study of Local Psychology, 92-147.

Jianhong, M., \& Chenming, N. (1998). An analysis of work value in chinese enterprises. Chinese Journal of Applied Psychology, 4, 10-14. doi: CNKI:SUN:YXNX.0.1998-01-001

Johnson, M. K. (2001). Change in job values during the transition to adulthood. Work and Occupation, 28, 315-345. doi: $10.1177 / 0730888401028003004$

Lan, G., Ma, Z. Cao, J., \& Zhang, H. (2009). A comparison of personal values of chinese accounting practitioners and students. Journal of Business Ethics, 88, 59-76. doi: $10.1007 / \mathrm{s} 10551-008-9829-6$

Lindeman, M., \& Verkasalo, M. (2005). Measuring Values with the short schwartz's value survey. Journal of Personality Assessment, 85, 170-178. doi: 10.1207/s15327752jpa8502 09

Lu, X. (2009). A chinese perspective: business ethics in china now and in the future. Journal of Business Ethics, 86, 451-461. doi: 10.1007/s10551-008-9857-2

Manhardt, P. (1972). Job orientations of male and female college 
graduates in business. Personnel Psychology, 25, 361-368. doi: DOI: 10.1111/j.1744-6570.1972.tb01111.x

Neitai, C. (2010). A study of the relationships among work values, leadership style, employees' characteristics and organizational citizenship behavior. Chung Yuan Christian University.

Posner, B. Z., Kouzes, J. M., \& Schmidt, W. H. (1985). Shared values make a difference: An empirical text of corporate culture. Human Resource Management, 24, 293-309. doi: $10.1002 / \mathrm{hrm} .3930240305$

Posner, B. Z., Randolph, W. A., \& Schmidt, W. H. (1987). Managerial values and across functions. Group \& Organization Management, 12, 373-385. doi: $10.1177 / 105960118701200402$

Pryor, R. G. L. (1980). Some types of stability in the study of students' work values. Journal of Vocational Behavior, 16, 146-157. doi:10.1016/0001-8791(80)90045-7

Schwartz, S. H., \& Rubel, T. (2005). Sex differences in value priorities: cross-cultural and multimethod studies. Journal of Personality and Social Psychology, 89, 1010-1028. doi:10.1037/0022-3514.89.6.1010

Super, D. E. (1970).Work values inventory manual. Boston: Houghton
Mifflin

Super, D. E. (1973). The work values inventory. In D. G. Zytowski (Ed.), Contemporary approaches to interest measurement (pp. 189-205). Minneapolis, MN: University of Minnesota Press.

Viola, R. (1977). Organizations in a changing society: Administration and human values. Philadelphia: Saunders, Co.

Weiwei, N. (1991). A review on occupation values. Studies on Social Psychoogy, 2, 34-40.

Wenquan, L., Liluo, F., \&Ligang, B. (1999). Study on the vocational value of Chinese undergraduates. Acta of Psychology, 31, 342-348.

Whitcomb, L. L., Erdener, C. B., \& Li, C. (1998). Business ethical values in China and the US. Journal of Business Ethics, 17, 839-852. doi:10.1023/A:1005793424492

Wollack, S., Goodale, J., Wijting, J., \& Smith, P. (1971) Development of the survey of work values. Journal of Applied Psychology, 55, 331-338. doi: 10.1037/h0031531

Yan, X., Fang, W., \& Huiyue, J., (2008). A comparison of values of undergraduates from Beijing and Sichuan after 512 Wenchuan earthquake. Psychology Exploration, 108, 46-50.

doi: 1003-5184(2010)01-0047-06 